\title{
'We Were Scared of Catching the Virus': Practices of Saudi College Students During the COVID-19 Crisis
}

\author{
Nada Bin Dahmash ${ }^{1}$ \\ ${ }^{1}$ College of Applied Studies and Community Services, King Saud University, Riyadh, Saudi Arabia \\ Correspondence: Nada Fahad Bin Dahmash, College of Applied Studies and Community Services, King Saud \\ University, Riyadh, Saudi Arabia. E-mail: naldahmash@ksu.edu.sa
}

Received: October 12, 2020

Accepted: November 16, 2020

Online Published: November 25, 2020

doi:10.5539/ijel.v11n1p152

URL: https://doi.org/10.5539/ijel.v11n1p152

\begin{abstract}
College students in Saudi Arabia engaged in various English activities in digital spaces during the COVID-19 crisis, despite it being their second language. Drawing on the concept of digital literacies proposed by Jones and Hafner (2012), this paper identifies the digital literacy practices that occurred in the English language during COVID-19 crisis. Focus group interviews and individual interviews were conducted via WhatsApp with ten college students who had recently attended an intensive English course at a university in Saudi Arabia. Thematic analysis, assisted by ATLAS.ti, revealed that the college students engaged in complex digital literacy practices in English during the COVID-19 crisis to improve their competency in English, educating the community and oneself about COVID-19 as well as to cope with the boredom of remaining indoors. College students mainly used smartphone apps in their literacies, and their usage was guided by their feelings, commitment and the contextual events around them. The literacies these students drew on reflected their metacognitive awareness of the value of English to their everyday life experience. This paper concludes by encouraging college students to exploit the potential of smartphone apps to improve their capacity in English and incorporate apps into their everyday lives.
\end{abstract}

Keywords: college students, COVID-19, digital literacies, English, Saudi Arabia

\section{Introduction}

COVID-19 was named in February 2020, and refers to the novel coronavirus that first affected people in Wuhan China before spreading around the world, leading international authorities to respond by taking action to contain its spread (World Health Organisation, 2020). Saudi Arabia was among the affected countries, and consequently the Saudi government decided to suspend students' physical attendance at universities requiring they study online utilizing digital methods (Al Thaqafi, 2020). The COVID-19 crisis drastically changed the lifestyles of people in Saudi Arabia, as they were required to remain indoors during the period of lockdown, self-isolating if they suspected themselves of being infected and maintaining social distance (Ben Gassem, 2020). The routine and lifestyle of college students, like that of other Saudi residents, changed as did their reasons for using English.

To date, explorations of students' use of English outside the classroom in Saudi Arabia have mainly been conducted with a pedagogical orientation, to determine the value of blogs, WhatsApp and Twitter in the English language learning and teaching context. Blogs are usually used and their value assessed in settings where students are required to improve their writing skills (Aljumah, 2012). Meanwhile, WhatsApp has attracted the attention of several scholars investigating the use of the platform as a substitute for the traditional classroom. Interactions in English on WhatsApp groups via texts or voice have been evaluated to examine the efficacy of using WhatsApp groups to reinforce what learners learned in school in online settings (Minalla, 2018). Engaging learners in interactions in English on WhatsApp groups, while they are being supervised by an instructor is one way to enhance their achievements in the four English skills: reading, writing, speaking and listening (Hamad, 2017). English texting on a WhatsApp group has been used as an approach to supplement writing courses, and improve learners' writing skills (Fattah, 2015) and improve the learners' vocabulary competency level (Bensalem, 2018). Twitter use has been trialed in settings where English writing courses were being delivered, to improve student's grammatical structures and vocabulary choices (Ali Said, 2015). These studies drew on experimental designs, whereby interactions on digital platforms had a particular pedagogic goal. The studies did not report on situations where English was being used outside a formal educational context, and so did not identify instances 
where the learners themselves independently initiated their engagement in English learning activities. In these studies, the interactions in English took place between peers and an instructor and were moulded by the instructor's intervention.

Future educational and pedagogical practices could be informed by researching people's literacy practices in their everyday lives (Barton \& Hamilton, 2012). This assertion was reinforced by the suggestion that drawing on the linguistic knowledge language learners already have, as well as their current language practices, could help teachers determine what content and reading strategies they need to teach (Barton \& Potts, 2013). Indeed, Alghamdi (2020) contended that exploring the social practices of language learners using English in different environments is vital when designing educational plans to meet students' needs.

It is essential to understand the social and contextual features that inform college students' use of English outside the school setting in uncertain times, such as during the COVID-19 pandemic, to understand how to support their learning processes when challenges arise. The findings of this study could provide an insight into classroom pedagogies. This paper, therefore, seeks to answer the following question:

- What digital literacy practices did college students perform in English during the COVID-19 crisis?

\section{Literature Review}

\subsection{Digital Literacies}

Literacy as a social phenomenon was first discussed in the 1980s, as part of the 'New Literacy Studies' approach, conceived of by scholars who refuted the notion that literacy, reading and writing, were purely cognitive abilities and technical skills. They viewed literacies in relation to the social and cultural contexts in which the activities of reading and writing take place (Jones \& Hafner, 2012). Subsequently, with the development of the online space, the process of engaging in the activities of reading and writing to perform everyday tasks in online settings was referred to as digital literacies (Barton \& Lee, 2013). These digital literacies, according to Jones and Hafner (2012), are non-linear, as reading and writing online takes the individual along non-sequential reading paths comprising multimedia, hypertexts and interactive components. Multimedia consists of more than one mode, integrating sounds, colours, videos, images and texts. Hypertexts are electronic texts embedded in hyperlinks, which take a user to another electronic text via the internet. The final component is the interactive component, which refers to the user's ability to interact with the text by writing and participating in online activities. Secker (2017) asserted that digital literacy not only refers to the skills and abilities required to perform activities in a digital environment; it also includes the practices and abilities that support learning in all settings. She stated: "the use of the word literacy signifies not the teaching of skills or competencies, but practices, attitudes and behaviours that are context specific" (Secker, 2017, p. 90).

To understand literacy, literacy scholars identify literacy practices. 'Practice' is used here to refer to observable literacy activities that involve people, feelings, resources and values (Tusting, Ivanič, \& Wilson, 2000). Literacy practices are not restricted to the print domain and evolve, taking different forms depending on the social context. Literacy practices within the digital domain refer to the approach people follow in their use of digital scripts to construct and represent their feelings, attitudes and social relationships (Baig et al., 2019). Digital literacy practices relate to how activities and meaning are created and developed by individual digital platforms to include other socio-cultural factors (Merchant, 2015).

The lens of literacy practices has attracted the attention of scholars interested in exploring the dynamics and minutiae of participants' practices in the online environment. The novel literacy practices of teenagers on Twitter (Gleason, 2016), literacy practices on Twitter hashtags (Gleason, 2018), new literacy practices on Facebook (Davies, 2012), gendered literacy practices of female hairdressers (Davies, 2013), and the literacy practices of college students in the UK that emerge as they engage in written assignments in digital settings (Bhatt, 2012) are all examples of how the literacy practices lens has been used to explore the literacy practices of participants who use English as their first language. In research by Barton and Hamilton (1998), literacy practices in the everyday lives of ordinary people in Lancaster were found to be hidden, purposeful, discouraged, learned informally and shaped by the people's daily needs.

The lens of literacy practices has also been used to explore the social aspects of people's literacies in contexts of uncertainty (Barton, 2011). He investigated the communication practices of people trapped in Norway, when seeking to resolve their difficulties when all flights were suspended due to a volcanic ash cloud. People communicated via mobile phones and used Google Translate website to translate between Norwegian and English, to assist them in decision making. They combined several practices: evaluating information consistently by listening to other people, managing rumours, and verifying what they were hearing with existing information. 
People sought out simple solutions by co-constructing knowledge in a fast and purposeful way from multiple resources. Spoken language was present in the public domain and so everyone heard each other's personal details, when booking hotels and credit card numbers. Written forms of the language, on the other hand, utilized new technology, and was not paper based, as people searched for information online, using their GPS systems to find the best routes home.

The literacy practices in the everyday lives of college students have been characterized as mostly multimodal, consisting of colour, movement, images, music and symbols, combined with written text, and also mostly multimedia consisting of different media (Ivanič et al., 2009).

This paper highlights the digital literacy practices in English of college students who were learning English when the COVID-19 pandemic occurred. The framework provided by digital literacy practices was used to guide this process, reviewing observable purposeful activities and skills associated with the social environment. These practices were also affected by social context, as the definition of literacy practices includes features such as resources, feelings, values and technology.

\subsection{Literacy Practices in English Among Language Learners in Saudi Arabia}

The literacy practices of the target students in English were investigated in the context of Saudi Arabia. Previous researchers in Saudi Arabia have examined students' performance and behaviours in terms of 'practices', e.g., Alghammas (2020) (i.e., he did not define his research in terms of digital literacies). He explored students' practices and attitudes when using the Cambly website to improve their speaking skills. He identified a potential setting for improving the speaking skills of Saudi students. His study involved 40 male college students majoring in the English Translation department at a Saudi university. He found that students regarded Cambly as an attractive setting in which to practice and engage in speaking activities with native speakers of English.

According to Bin Dahmash (2019) and Alghamdi (2020), the practices of female college students can be used to refer to patterns of behaviour distinct from literacy events. Bin Dahmash (2019) explored the literacy practices of seven Saudi undergraduates using English on social media drawing on ethnographic tools. She found, the activities of reading and writing on social media were intertwined, and could not be separated or treated as reading only or writing only. Her study identified ten categories of everyday life: documenting life, enriching the knowledge of Twitter audience, opinions and advice, personal communication, social media affordances, addressing oneself in public, expressing feelings, removing unpleasant memories, entertainment and correcting English. On the other hand, Alghamdi (2020) explored literacy practices in educational settings through a case study and qualitative approach. She evaluated the literacy practices of female undergraduates majoring in Pharmacy at university in Saudi Arabia engaged in an oral presentation of English. She found that students considered linguistic accuracy in their presentation. This was demonstrated through the student's social practices when experiencing regular exposure to English, when consulting with colleagues, in translating resources from Arabic to English, and in responding to instructor's feedback.

When the data collection for the three studies described above took place, students were experiencing an ordinary academic environment; however, the participants in the current study were struggling to cope with COVID-19. As the current global crisis is unprecedented, it affords a unique opportunity to examine how challenging times affect how Saudi students perform digital practices in English.

\subsection{Agency}

Learner agency is a contested term, with current understanding of its role in language learning predicated on the proposition by Lier (2010) that the agency of learners is vital. He defined agency as the movement and choices a person engages in to attain his goals in learning; observing that without activating his agency a learner cannot progress towards learning a particular language. He contends that autonomy and motivation are the products of agency, and can be triggered by both the individual and their surrounding social environments. Agency is essential in participation and second language learning (Duff \& Doherty, 2014). From this viewpoint, the opportunities a second language learner creates and takes advantage of determines their agency.

According to Jones (2017), the agency of people when participating in activities is linked to literacy practices. He highlighted the agency of individuals when performing their literacies in digital settings. He hypothesised that the choices a person makes, and the opportunities he takes to perform different literacies, determines the extent of his learning and engagement. The degree of a person's learning when engaged in activities was asserted under the notion of situated learning (Chaiklin \& Lave, 1993). According to the concept of situated learning, an individual learns when engaged in multiple activities, regardless of his intention to learn. This has been referred to as an informal learning process and it is when knowledge is embedded by individuals as they employ literacy 
practices (Hamilton, 2006).

Based on the above, agency affects the literacy practices college students perform when engaging in activities in English while navigating the COVID-19 crisis. Their literacies affect their use and learning of English as a second language. Since the literacy practices of college students impact how they use and learn English, and how they enact their agency to reach their goal, this study aims to identify the literacy practices of college students in their everyday routines, during the COVID-19 pandemic. This is important, because the choices they make and the opportunities they take advantage of might be impacted by the measures Saudi Arabia has implemented to tackle the spread of the virus.

\section{Methodology}

This study used qualitative research tools with focus group interviews and individual interviews to gain an in-depth understanding of the digital literacy practices that participants performed in English during the COVID-19 crisis. Focus group interviews provide researchers with differing viewpoints on specific issues (Brinkmann \& Kvale, 2018), and can provide rich details of participants experiences and values regarding issues in dynamic discussion (Morgan \& Hoffman, 2018). Individual interviews are valuable as a means to gain an in-depth understanding of certain issues from a single individual's perception (Kvale, 2007). The participants selected the online platform and all the interview sessions were administered via WhatsApp synchronously over seven- weeks, beginning in July 2020. The interviews were conducted in an online setting, because the data was collected during the spread of COVID-19, when participants in the physical world were required to wear face-masks and meeting other people were limited due to the two-meter social distancing rule imposed in Saudi Arabia. Interviews were conducted in Arabic as chosen by the participants. Two focus group interview sessions were conducted with five participants attending each session via WhatsApp group. The individual interviews were conducted in two phases: the first involved ten participants and the second eight participants; all via WhatsApp private chatting (see Table 1). The participants attached screenshots and videos on WhatsApp to illustrate their accounts of their digital practices. The focus group interviews were conducted before the individual interviews to develop the participants' collective understanding. The second individual interviews were conducted after the initial analysis of both the focus group sessions and the first individual session.

Table 1. Research participants and types of interviews and media collected

\begin{tabular}{llllll}
\hline $\begin{array}{l}\text { Name of } \\
\text { Participant }\end{array}$ & $\begin{array}{l}\text { Focus-group } \\
\text { interview (1) }\end{array}$ & $\begin{array}{l}\text { Focus } \\
\text { group-interview (2) }\end{array}$ & $\begin{array}{l}\text { Individual } \\
\text { interview (1) }\end{array}$ & $\begin{array}{l}\text { Individual } \\
\text { interview (2) }\end{array}$ & $\begin{array}{l}\text { Media attached on } \\
\text { WhatsApp }\end{array}$ \\
\hline Participant 1 & & $\sqrt{ }$ & $\sqrt{ }$ & $\sqrt{ }$ & 8 screenshots and 2 videos \\
Participant 2 & & $\sqrt{ }$ & $\sqrt{ }$ & $\sqrt{ }$ & 8 screenshots \\
Participant 3 & $\sqrt{ }$ & $\sqrt{ }$ & $\sqrt{ }$ & $\sqrt{ }$ & 5 screenshots \\
Participant 4 & & $\sqrt{ }$ & $\sqrt{ }$ & $\sqrt{ }$ & 4 screenshots \\
Participant 5 & $\sqrt{ }$ & $\sqrt{ }$ & $\sqrt{ }$ & $\sqrt{ }$ & A screenshot \\
Participant 6 & & & $\sqrt{ }$ & $\sqrt{ }$ & 5 screenshots \\
Participant 7 & $\sqrt{ }$ & $\sqrt{ }$ & $\sqrt{ }$ & $\sqrt{ }$ & 5 screenshots \\
Participant 8 & $\sqrt{ }$ & $\sqrt{ }$ & $\sqrt{ }$ & $\sqrt{ }$ & 2 screenshots \\
Participant 9 & & $\sqrt{ }$ & & &
\end{tabular}

\subsection{Participants}

The researcher contacted one of her students who had recently finished an intensive English course inviting her to participate by sending a WhatsApp message containing information about the study. The participant voluntarily agreed to participate and the researcher asked her to invite others who met the criteria of this study; i.e., having completed an English course recently in a particular college. Participants contacted the researcher via WhatsApp to participate in the study. Participants who were studying outside a particular college were removed. This type of sampling process is referred to as snowball sampling (Morgan, 2008). Ten students studying at King Saud University in Saudi Arabia participated in this study.

\subsection{Ethics}

The participants received two messages on WhatsApp describing the aims of the research and what it entails. The first information message detailed the scope of the study, the methods used, the duration of the data collection period, issues associated with data protection and that participation is voluntarily, and that there would be no financial gain to ensure the study conforms to digital research ethics (Tiidenberg, 2018). The second 
session of the individual interviews was conducted after the initial process of analysing data from the focus group interviews and the first individual interview sessions was complete. It was decided upon when it became apparent that the researcher required further explanation of some of the themes that had emerged during the analysis. Accordingly, the same participants were invited to participate in the second individual interview, and received an information message via WhatsApp, explaining why it was necessary to conduct a second session of individual interviews; two participants withdrew.

\subsection{Data Analysis}

The data analysis was carried out by applying Saldaña's (2016) systematic coding approach and Brinkmann and Kvale's (2018) thematic analysis. The analysis was carried out on ATLAS.ti software to assist in increasing the reliability and credibility of the qualitative analysis process (Cohen, Manion, \& Morrison, 2018). ATLAS.ti assisted in attaching codes to chunks of data, ensuring linking between codes, retrieval of data based on researcher's search criteria, displaying codes and saving the researcher's memos (see Friese, 2014). Two frames of coding were used: concept-driven (deductive) codes, and data-driven (inductive) codes. The WhatsApp chats (in texts) were exported along with media attached from the researcher's iPhone and saved to a secured laptop. After this, all the data was imported into the ATLAS.ti software to prepare the analysis process. The researcher analysed the raw data so as to maintain the fundamental nature of the participant's discussion and translated the transcript from Arabic into English to present herein. The transcripts of the interviews were read several times and deductive codes added at the beginning to certain parts of the texts, as were screenshots such as 'smartphone app' and 'activities'. After this, inductive codes were added to parts of the texts and screenshots highlighting phrases such as 'raise awareness' and 'enjoy time'. The codes were then grouped, renamed and displayed in the 'network' on the ATLAS.ti to assist the researcher in generating themes to answer the research question.

\section{Results and Discussion}

The data suggests that the digital literacy practices of college students during the COVID-19 crisis in English can be arranged into three major themes. These themes were: 1) improving competency in English; 2) educating the community and oneself about COVID-19; and 3) coping with boredom arising from remaining indoors (see Figure 1). This section, therefore, addresses the research question and relates the results to previous literature.

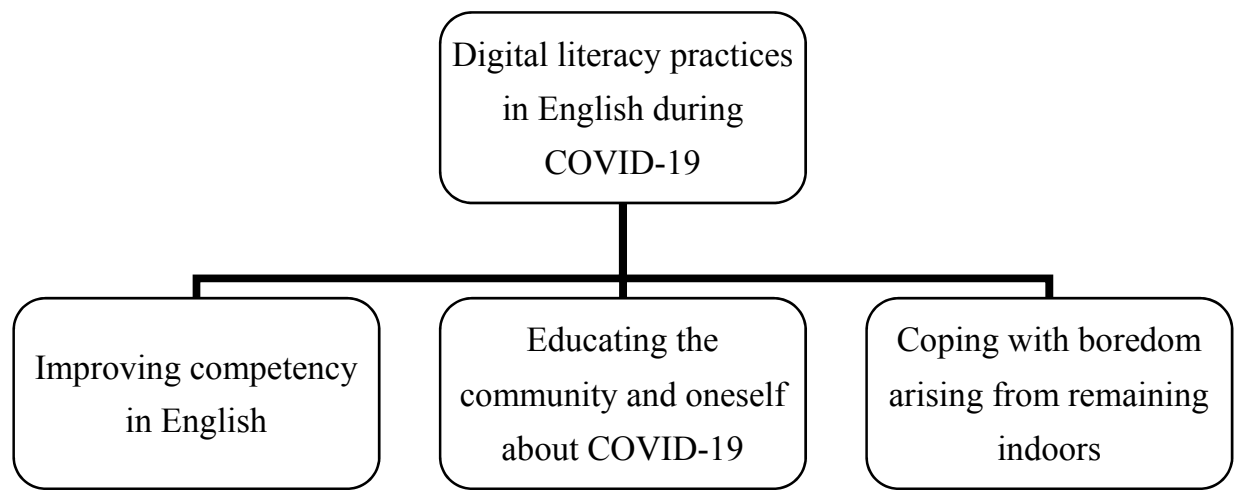

Figure 1. Digital literacy practices in English

\subsection{Improving Competency in English}

Digital literacy practices were performed to improve the college student's competency in English when using smartphone apps and accessing websites via internet browsers on their smartphone or iPad. The participants listed eight smartphone apps they drew on to improve their English. Participant 8, in focus group (1), explained that she uses a particular feature on Twitter to translate from Arabic into English, and as a way to increase her vocabulary by tapping on the 'Translate Tweet' found in the middle left area of the tweet (see Figure 2A). The 'Duolingo' app was downloaded by Participant 10, so that she could improve her speaking skills by engaging in fun and motivating games. This app is a free language learning app known to promote language learning while engaging the learner in short tasks and activities, such as speaking, listening, reading and translation, and then automatically corrects these tasks to provide users with rewards that enable them to purchase their products in the app shop (see Teske, 2017).

A comprehensive account of the smartphone apps used to improve competency in English was given by 
Participant 2. She identified six smartphone apps that enhanced her English language skills: Google, Learn English Podcast, Twitter, Telegram, Microsoft Translation and Snapchat. She mentioned that Google was used to research how to 'write a formal email' (see Figure 2B). This goal was accomplished by tapping the hyperlinks suggested by Google and reading through examples. The Learn English Podcasts app was used to improve listening comprehension and Twitter enriched the learner's ability to produce accurate grammatical structures in English. This was achieved as a result of exposure to the tweets for the 'Learn English' Twitter account managed by the British Council, which contained hyperlinks to other certified pedagogical websites designed to increase second language learner's grammatical competency.

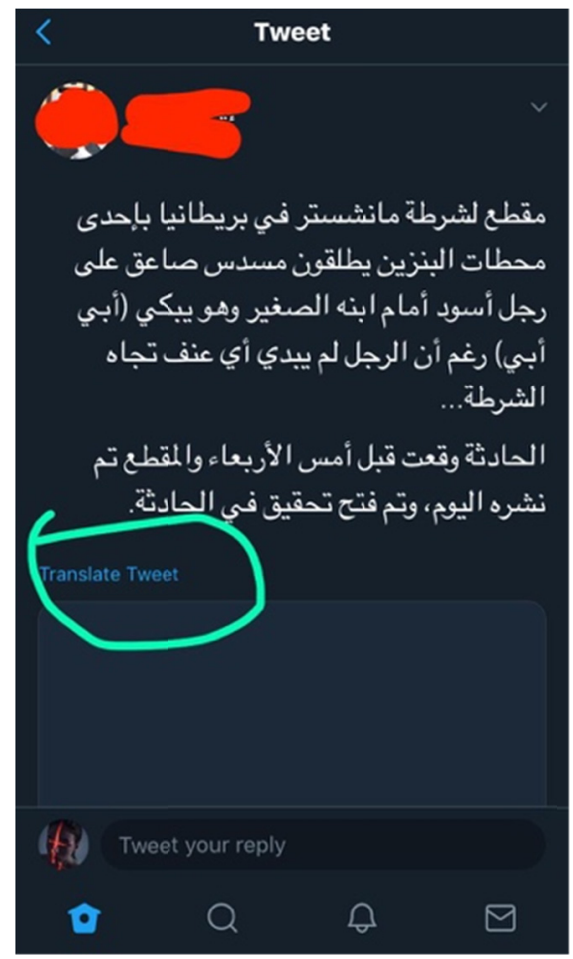

A

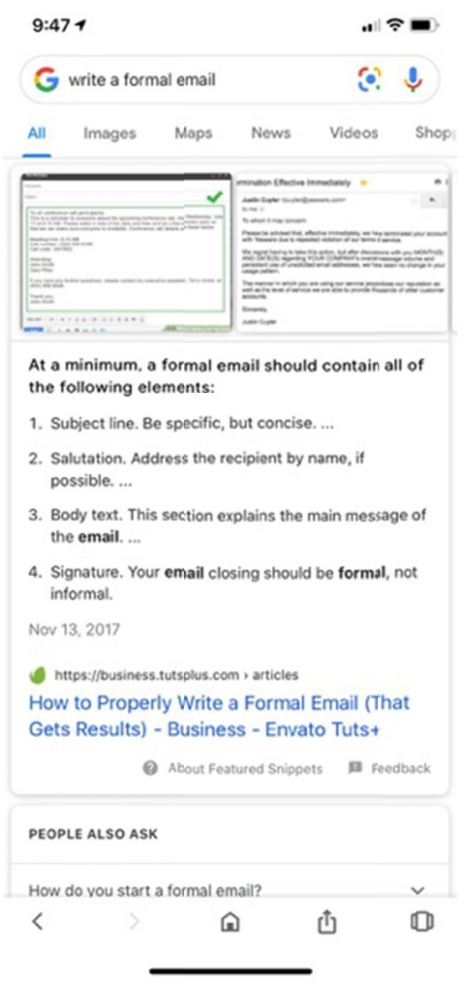

B

Figure 2. Feature illustrating how to translate a tweet from Arabic into English in A and instructions on email writing in $\mathrm{B}$

Practices in English on Telegram involved group work, designed specifically to teach English. The activities engaged within these Telegram groups aimed to improve learners' overall English competency. Daily lessons were posted via links and included pictures detailing particular linguistic aspects, requesting that group members text in English. These Telegram groups instruct members to engage in English only in all activities and restrict their involvement in texting. Those members who did not adhere to these guidelines were removed. The Telegram groups then replaced the walls of the language classroom with a digital setting.

Practices on Snapchat undertaken to improve language competency, assessed vocabulary knowledge through multiple-choice questions (see Figure 3A). This assessment process resembles language testing conducted in a pedagogical environment. Microsoft's Translation in English practices were used to translate words and sentences from English into Arabic and vice versa. The 'English Listening' app was reportedly utilized to assist the college students with realizing their potential in English as their second language. Participant 7 reported that listening and reading were performed simultaneously by playing one episode of 'English Listening' app (see Figure 3B). Reading through the app was an interactive process, as the app highlights the sentences as they are played in yellow. Each conversation on that app lasts six minutes, and explanation for some of the vocabulary items are presented at the end of episode. 


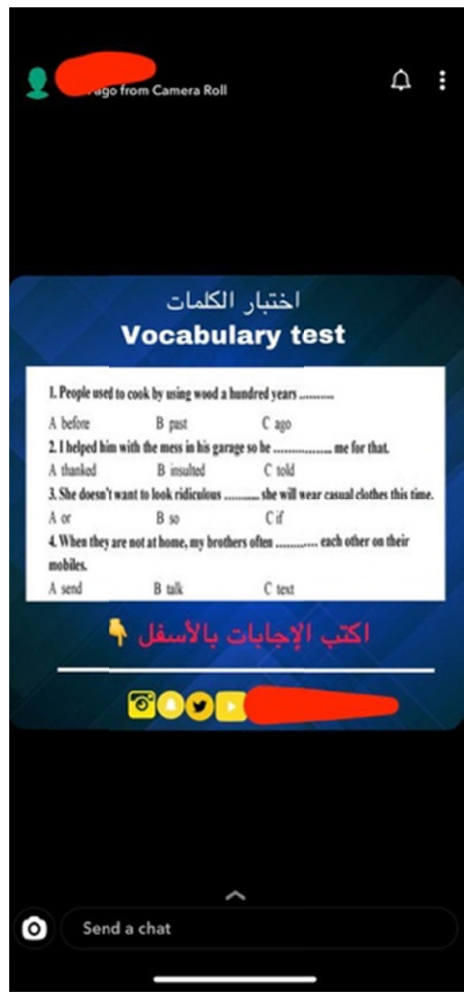

A

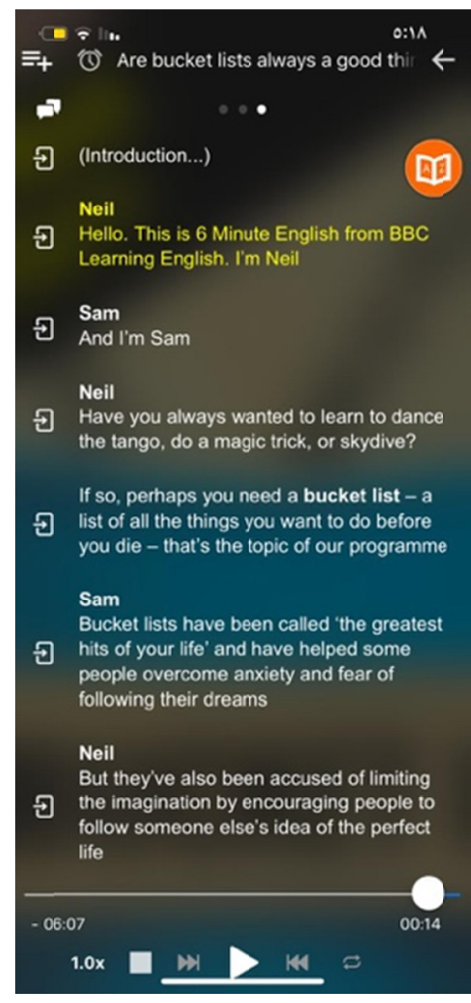

$\mathrm{B}$

Figure 3. A vocabulary test on Snapchat in A and a conversation taken from English Listening app in B

Practices on Google Scholar in English were drawn upon to improve the learners' reading speed and skill. This was accomplished by typing English phrases into the search bar on the iPad and reading through the research output by clicking on the hyperlinks. The Cambridge dictionary website was used to search for the meaning of certain words in English, and identify synonyms to establish how the word could be used in context.

[12/07/2020, 10:39:44 pm] Participant 5: Since we tried distant learning, we were encouraged to learn the things we love in English remotely. So, no certificates no university

[12/07/2020, 10:39:59 pm] Participant 7: Ture

[12/07/2020, 10:40:04 pm] Participant 8: True

[12/07/2020, 10:40:22 pm] Participant 10: I I agree

[12/07/2020, 10:40:51 pm] Participant 3: Add on this point. Websites created free webinars and free workshops. Distant too. Other press agencies offered their books $\$$ to be read free online. Everyone was cooperating , there was a big support from the outside world Alhamdulillah

[12/07/2020, 10:41:09 pm] Researcher:

[12/07/2020, 10:41:30 pm] Participant 3:

[12/07/2020, 10:41:53 pm] Researcher:

[12/07/2020, 10:41:59 pm] Participant 3:
Were all these in English?

Yes, of course in English. For all these things and the support we have received, we were encouraged to improve ourselves without having to learn by force or being something we are obliged to do

So, you were motivated to learn outside university

Yes of course 
[12/07/2020, 10:42:17 pm] Participant 10:

[12/07/2020, 10:42:26 pm] Participant 3:

[12/07/2020, 10:42:45 pm] Participant 7:

[12/07/2020, 10:42:48 pm] Participant 8:

[12/07/2020, 10:43:34 pm] Participant 10:

[12/07/2020, 10:43:58 pm] Participant 5:
Yes, even entertainment books and stories were free. Even novels were free. We benefited more

We had plenty of time. We couldn't go outside. We were scared of catching the virus and our whole life turned upside down . So, it was time to think for the future and work on ourselves

Yes. We had all the resources and we were encouraged to learn freely. Nothing was imposed or compulsory. All was optional

I agree. We had all resources

Agree

True. We had everything to improve our situation

(Excerpt from the focus group interview (1) translated from Arabic)

From this excerpt, it is apparent that the participants were motivated to exploit websites designed to teach and enhance their English, after exposure to pedagogical materials to learn English in virtual classes. It appears that the environment of the COVID-19 crisis cultivated autonomous English language learning for two reasons. The first was the educational resources were provided to all learners free of charge and the set of learners involved in this research perceive the benefits of these resources. The other reason was the excess time these college students reported having to spend on learning, as they were required to stay indoors to protect themselves and others from COVID-19. Learner's agency was enacted as they willingly took the opportunities presented to them in this unique environment (Lier, 2010).

The findings concerning the smartphone apps the participants in this research reported using when engaging in literacy practices to improve their English during the COVID-19 crisis correspond with results from Alrefaai (2019) and Al Mukhallafi (2019), who reported that students at universities in Saudi Arabia have a positive attitude towards using mobile apps to learn English. The digital literacy practices of college students mostly involved using smartphones and this result is consistent with results by Warni, Abdul Aziz and Febriawan (2018), who mentioned that students in Indonesia use mobile phones in their everyday lives to learn English outside the classroom.

The use of Google app and Google Scholar adds to the findings detailing the positive influence of Google products on language learning (Ambrose \& Palpanathan, 2017; Amin, 2020; Bin Dahmash, 2020; Chinnery, 2008). Literacy practices to improve competency in English were learned informally outside the school setting, and share the characteristics of vernacular literacies (see Barton \& Hamilton, 1998). The use of Duolingo to improve the speaking skill in English is in line with the finding of Finardi, Leao and Amori (2016), who suggested that Duolingo assists language learners with improving their grammar and vocabulary competency. The use of Telegram groups to learn English using a systematic approach through lessons correlated with evidence presented by Abu-Ayfah (2020), who reported that undergraduates employ Telegram for English learning purposes.

\subsection{Educating the Community and Oneself About COVID-19}

Digital literacy practices in English were also partially engaged in to increase the students' knowledge about COVID-19. This led them to engage with activities on three smartphone apps and activities in virtual classroom settings. Different accounts on Twitter provided information about COVID-19, enabling the participants to learn about how to protect themselves from infection, such as the correct way to wear a mask (see Figure 4A). The Ministry of Health (MOH) in Saudi Arabia's official Twitter account was followed by all the participants, providing them with regular updates on coronavirus. The MOH tweets in Arabic and English to update individuals about the situation with regard to COVID-19 in Saudi Arabia, and provides key pointers at the daily press conference in the form of English texts and infographics. Participant 5 reported that she read these tweets on a daily basis as they were the only reliable source of information in Saudi Arabia (see Figure 4B). Participant 4 mentioned she did not intend to follow the Twitter accounts in English that provided information about coronavirus; however, she found $\mathrm{MOH}$ tweets in English attractive, as they contained both short sentences in English and infographics (see Figure 4C). Infographics are "an approach to presenting data (possibly from complex combined databases) in a single image" (Infographics, 2016). Reading trending hashtags on Twitter related to news on COVID-19 helped maximize the college student's knowledge of the virus. The hashtags in the 
tweets directed the participants to other tweets written in English and included hyperlinks to other websites with videos in English.

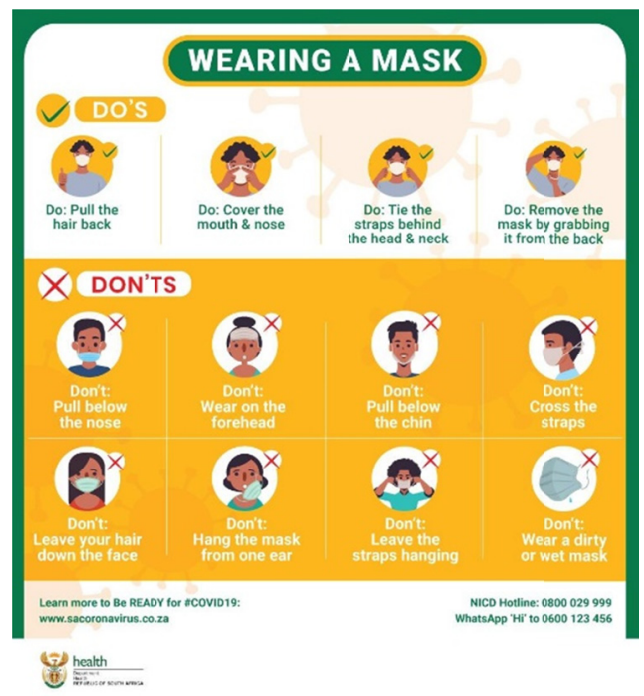

A

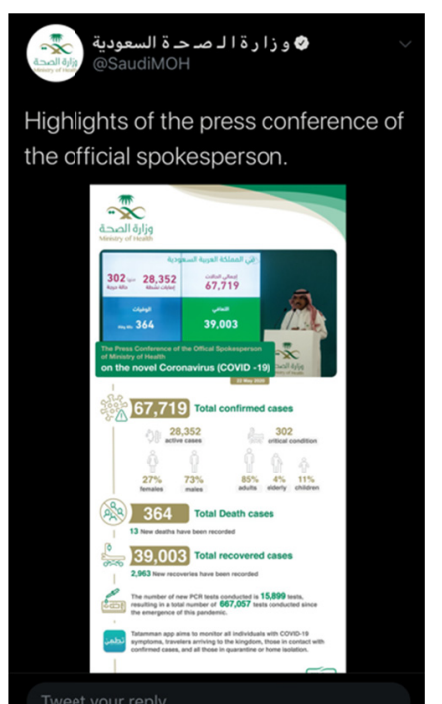

B

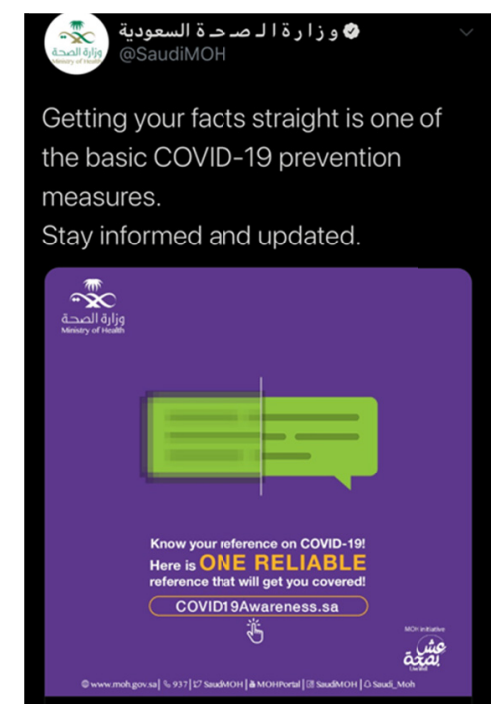

$\mathrm{C}$

Figure 4. A tweet about the correct way to wear a mask in A, a tweet briefing $\mathrm{MOH}$ press conference in $\mathrm{B}$, and a tweet provided by Participant 4 from $\mathrm{MOH}$ account in $\mathrm{C}$

Some posts on Instagram serve to advance the knowledge of the wider community regarding COVID-19, offering many resources and tools. Participant 3 reported that as a result of the coronavirus outbreak she had designed infographics to help raise people's awareness of how to protect themselves and others from the disease, and posted relevant infographics on Instagram (see Figure 5A). She commented that as a member of the 'smile you are blessed' initiative, which supports people who suffer from cancer in Saudi Arabia, it was her responsibility to raise people's awareness about health-related issues. She achieved this by designing infographics and drawing on texts in English using colourful fonts to portray particular information.

COVID-19 inspired some of the participants to choose topics on issues related to the disease to present orally in virtual classes, to increase others' knowledge. Participant 9, for example, decided to raise her own awareness and that of her colleagues on the English-speaking course and her friends using a Snapchat story, in an innovate approach. Her chosen topic was COVID-19 and how it spreads, and she planned and conducted a spoken presentation. Participant 9 explained that she watched the movie 'Contagion' several times to learn about how epidemics spread, and how people react to them, as well as the influences of a contagious disease on multiple aspects of people's lives. After that, a PowerPoint presentation was created to assist the student in discussing the movie and providing essential information about COVID-19 as part of a virtual class. Events in the movie were compared to events occurring in the real world as people respond to COVID-19. Photographs were taken by Participant 9 herself while presenting. These photos were later posted on Snapchat to enhance the knowledge of her Snapchat friends and her colleagues in the virtual class (see Figure 5B). 


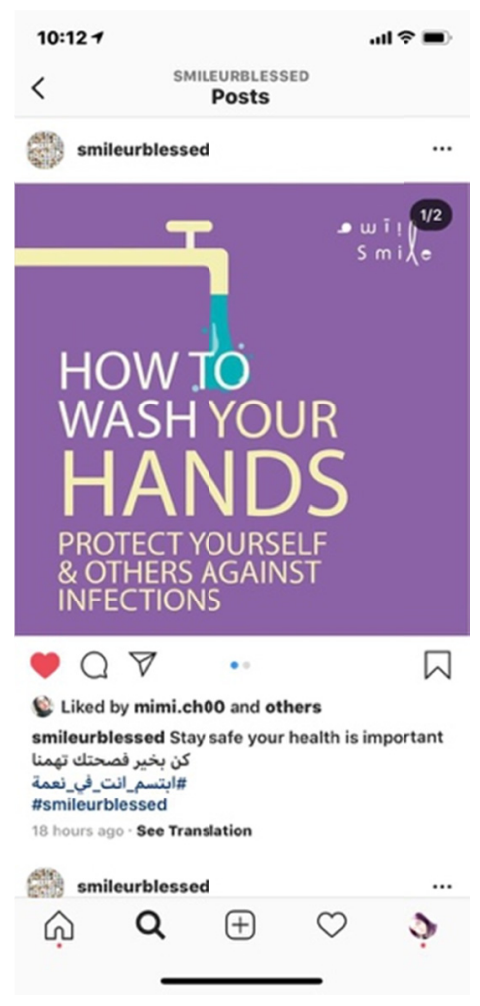

A

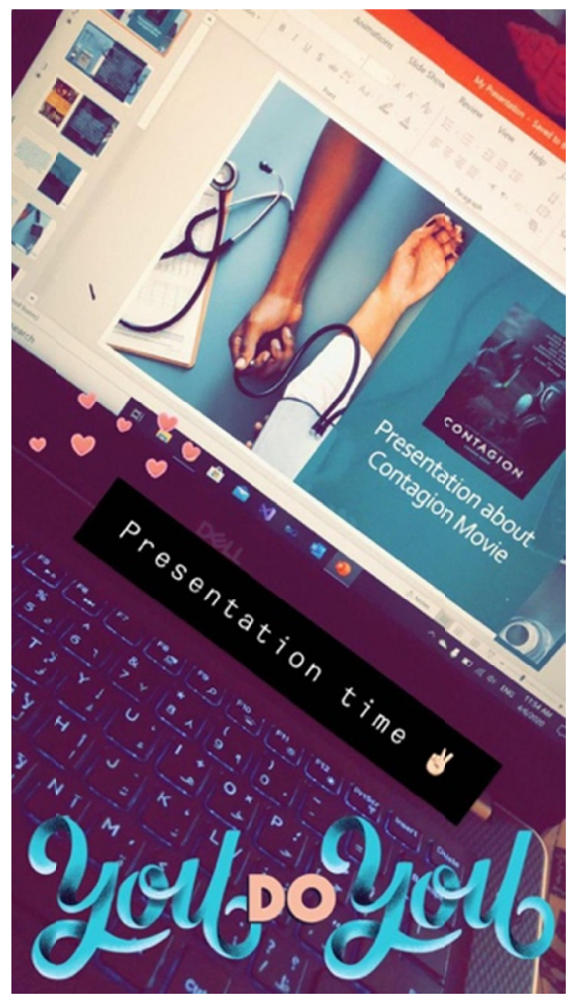

B

Figure 5. Instagram post in A and a photo of Participant 9's presentation posted on Snapchat story in B

From these results, digital literacy practices relating to bolstering one's own knowledge, and that of the community, concerning COVID-19 were innovative and complex and mediated via smartphone apps and virtual classes. They included technical tools, such as computer software and TVs, and also integrated photos and infographics. Participant 3 engaged in various literacy practices, drawing on English texts and colourful pictures to design infographics and share them on Instagram to enrich the knowledge of those who follow her 'smile you are blessed' account. Participant 9 performed multiple digital literacy practices, and watched a movie in English and used PowerPoint to integrate English texts and photographs when designing her presentation. These digital practices were multimodal, containing texts in English, images, colours, sounds and multimedia, which are all elements of digital literacy practices (Bhatt, 2012; Gleason, 2016; Jones, 2017; Jones \& Hafner, 2012); their activities shared elements with those of college students in the UK (Ivanič et al., 2009). The results regarding literacy practices in English aimed to raise the knowledge of Instagram and Snapchat followers, corresponding with results reported by Bin Dahmash (2019), who found that undergraduates use literacy practices to enrich the knowledge of their Twitter followers in English.

\subsection{Coping with Boredom Arising from Remaining Indoors}

The digital literacy practices that college students engaged in during the COVID-19 crisis were also performed in part to cope with the boredom caused by remaining indoors to stay safe. They utilized their time interacting with smartphone apps, built-in features on their smartphones and watching news and movies on their TVs and iPads.

[15/07/2020, 11:02:58 pm] Researcher: What did you do in English during COVID-19

[15/07/2020, 11:02:58 pm] Participant 1: I chatted with Siri @) believe it or not

[15/07/2020, 11:03:11 pm] Participant 4: I downloaded an app I used to have $\searrow$ I was bored

[15/07/2020, 11:03:54 pm] Participant 9: I watched movies. I had plenty of time

[15/07/2020, 11:04:08 pm] Participant 1: I tried an app not for studying or university. Just to chat with native speakers and leave the house in 
my brain without face-mask and hand sanitisers

[15/07/2020, 11:04:15 pm] Participant 1: Cambly

[15/07/2020, 11:04:19 pm] Researcher: Nice :-:0

[15/07/2020, 11:04:22 pm] Participant 2: I wait for Trumps' hilarious talk@ he kills time

[15/07/2020, 11:04:25 pm] Participant 6:

[15/07/2020, 11:04:25 pm] Participant 4: Me too:- $\mathrm{x}$ (nothing to do but TV

(Excerpt from the focus group interview (2) translated from Arabic)

The excerpt shows that the participants in focus group (2) engaged in digital practices involving the built-in smartphone feature named 'Siri', a smartphone app named 'Cambly', watching movies, and watching the daily press conference by Donald Trump, the President of the United States. Participant 1 provided a detailed description of how she used 'Siri' and Cambly during the individual interviews. Siri is a built-in feature of the iPhone that virtually assists users to search for information by voice, answer questions, and engage in basic conversation (Siri, 2020). Boredom prompted her to speak with 'Siri' in English as she had fun 'playing with words', as she described it. Siri's reactions to illogical commands amused and entertained Participant 1, especially when Siri replied with "I don't know". Engaging with Cambly involves subscribing to a lesson plan on an app which enables a user to select a native speaker to talk to and engage with in interesting activities in English. Participant 1 was proud of being able to converse fluently with someone whose L1 was English, and she shard two videos of one minute long detailing the lessons on Cambly. One of the videos showed that Participant 1 was motivated to talk about interesting topics, such as explaining fasting during Ramadan. She is a Muslim and was fasting, so she explained this Islamic obligation to the instructor who then engaged in a dialogue with her about it.

Movies on smart TVs and iPad were watched as a way to pass the long hours of staying indoors. Participant 5 reported that she subscribed to Netflix during the active spread of COVID-19 to watch series with multiple episodes and seasons. She explained that she sometimes watches the movies and series with English subtitles, because not all movies and series are available with subtitles in Arabic. Participant 9 and Participant 3 also reported that they watched movies in English on smart TVs to help them enjoy their time.

Watching the press conference held by Donald Trump, the President of the United States, was reported to be among the popular English activities that some participants spent their free time on. These participants stressed that they watch the press conference without translation into Arabic, so they could listen to Trump's humorous voice on TV. Participant 7 stated that watching Trump's press conference live at midnight enabled her to learn about the latest innovations to treat COVID-19 in a fun way. She stated that Trump mentioned injecting patients with disinfectant to kill the virus and that this suggestion was a joke; she strongly believed that Trump was attempting to ease Americans' fear of the virus. Participant 6 mentioned that she started watching the press conference after the viral spread of Trump's video in which he named COVID-19 the 'Chinese virus'. She stated that she received the video by WhatsApp and thought his face was funny.

Smartphone apps such as Snapchat, YouTube and PUGB were reportedly among the apps that engaged the students literacies in English to entertain themselves as they stayed indoors. Participant 3 reported in focus group (1) that she follows famous people on Snapchat, as they post videos about their daily life in the lockdown. Participant 7 and Participant 10 similarly reported that they were interested to see how celebrities cope with the quarantine. Participant 3 managed boredom by watching 'how to' videos on YouTube, as a way to learn to cook or become a makeup artist. Participant 8 mentioned that ever since she had downloaded the 'PUBG' game app on her smartphone she had become much busier and was rarely bored. She explained that she speaks in English with the other players who use the game, as they do not understand Arabic. She played 'PUBG' as a leisure activity during COVID-19 and used it to socialize with people in the virtual world.

In this research a key reason college students utilized diverse literacies in English as they remained indoors was to manage the boredom arising from being indoors to prevent the spread of COVID-19. Participants engaging with Siri, Cambly or playing 'PUBG' and watching YouTube were able to move from one place to another virtually, thereby accessing different insights into the world. The act of 'travelling' in this way enabled them to overcome the restrictions of the physical world. Previously this type of 'mobility' was identified as an important feature of digital literacies (Jones, 2017). The participants attempted to spend their free time engaging in multiple literacies, such as speaking and listening, and using available materials to help them live life more pleasurably. They followed a press conference presented by a political leader, and viewed the event as a key entertainment resource. They focused on meaning as delivered through the use of English and other resources when listening and watching 
a Snapchat story. The finding pertaining to the use of Cambly echoed Alghammas' (2020) study, which considered the practices on Cambly undertaken by male college students in Saudi Arabia and found it to be an attractive environment.

\section{Conclusion}

The digital literacy practices of college students during the Covid-19 crisis were performed to increase capacity in English, raise knowledge of oneself and their local community regarding COVID-19 and manage boredom of staying indoors. These literacies were innovative and complex as the Saudi students drew on multiple resources available in the digital environment, accessing multiple smartphone apps. The college students valued improving their capabilities in their second language, engaging in opportunities to practice English that reflected their metacognitive awareness of the significance of English. They differentiated between activities they used to learn English and those they engaged in to fulfil other needs. They showed appreciation and commitment to raise the knowledge of their local community about COVID-19 in English. This study expands understanding of the digital literacy practices of Saudi college students in English outside of educational settings during the COVID-19 crisis.

The findings reported here have a number of implications for language learners and language instructors. Learners can be encouraged to improve their listening skills by using the 'English Listening' app and the 'Learn English Podcast' app, as the study found they provide an array of conversations and topics to choose from. Learners could also watch movies on Netflix with subtitles in English to improve both their reading and listening skills. Learners could also speak with Siri to enhance their pronunciation and speaking skills. English Language instructors could modify their teaching techniques to provide a more attractive and natural environment to motivate students. Instructors could also create a Telegram group to allow learners to text in English and provide additional supplementary materials for English courses via that group.

\section{References}

Abu-Ayfah, Z. A. (2020). Telegram app in learning English: EFL students' perceptions. English Language Teaching, 13(1), 51-62. https://doi.org/10.5539/elt.v13n1p51

Al Mukhallafi, T. R. (2019). Attitudes and usage of MALL among Saudi university EFL students. International Journal of English Linguistics, 9(1), 407-420. https://doi.org/10.5539/ijel.v9n1p407

Al Thaqafi, T. (2020, March 9). Saudi education sector switches to virtual classrooms. Arab News. Retrieved October 12, 2020, from https://arab.news/2zpjc

Alghamdi, N. A. (2020). English-mediated presentations in Pharmacy: Exploring literacy practices among Saudi female undergraduates. Arab World English Journal, 11(2), 275-289. https://doi.org/10.24093/awej/vol11no2.19

Alghammas, A. (2020). Web-based synchronous speaking platforms: Students' attitudes and practices. International Journal of English Linguistics, 10(3), 21-31. https://doi.org/10.5539/ijel.v10n3p21

Ali Said, M. A. E. (2015). The effect of Twitter on developing writing skill in English as a foreign language. Arab World English Journal, Special issue on CALL(2), 134-149. https://doi.org/10.2139/ssrn.2843985

Aljumah, F. H. (2012). Saudi learner perceptions and attitudes towards the use of blogs in teaching English writing course for EFL majors at Qassim University. English Language Teaching, 5(1), 100-116. https://doi.org/10.5539/elt.v5n1p100

Alrefaai, I. (2019). Exploring EFL graduate students' attitudes toward, and use of, mobile phones in language learning. Arab World English Journal, 1, 70-84. https://doi.org/10.24093/awej/efl1.6

Ambrose, R. M., \& Palpanathan, S. (2017). Investigating the effectiveness of Computer-Assisted Language Learning (CALL) using Google Documents in enhancing writing-A study on senior 1 students in a Chinese independent high school. IAFOR Journal of Language Learning, 3(2), 85-112. https://doi.org/10.22492/ijll.3.2.04

Amin, E. A.-R. (2020). A review of research into Google apps in the process of English language learning and teaching. Arab World English Journal, 11(1), 399-418. https://doi.org/10.24093/awej/vol11 no1.27

Baig, F. Z., Yousaf, W., Aazam, F., Shamshad, S., Fida, I., \& Aslam, M. Z. (2019). Power, ideology and identity in Digital Literacy: a sociolinguistic study. International Journal of English Linguistics, 9(4), 252-264. https://doi.org/10.5539/ijel.v9n4p252

Barton, D. (2011). People and technologies as resources in times of uncertainty. Mobilities, 6(1), 57-65. 
https://doi.org/10.1080/17450101.2011.532652

Barton, D., \& Hamilton, M. (1998). Local literacies: Reading and writing in one community. London: Routledge.

Barton, D., \& Hamilton, M. (2012). Local literacies: Reading and writing in one community (rev. ed.). London: Routledge. https://doi.org/10.4324/9780203125106

Barton, D., \& Lee, C. (2013). Language online: Investigating digital texts and practices. Abingdon: Routledge. https://doi.org/10.4324/9780203552308

Barton, D., \& Potts, D. (2013). Language learning online as a social practice. TESOL Quarterly, 47(4), 815-825. https://doi.org/10.1002/tesq.130

Ben Gassem, A. (2020, May 27). Saudis learning to live with lessons learned from COVID-19 pandemic. Arab News. Retrieved October 12, 2020, from https://arab.news/bwn5h

Bensalem, E. (2018). The impact of WhatsApp on EFL students' vocabulary learning. Arab World English Journal, 9(1), 23-38. https://doi.org/10.24093/awej/vol9no1.2

Bhatt, I. (2012). Digital literacy practices and their layered multiplicity. Educational Media International, 49(4), 289-301. https://doi.org/10.1080/09523987.2012.741199

Bin Dahmash, N. F. (2019). Investigating the social media literacies of female undergraduates in English: An ethnographic case study from Saudi Arabia. PhD thesis, Lancaster University, UK.

Bin Dahmash, N. F. (2020). 'I Can't live without Google Translate': A close look at the use of Google Translate app by second language learners in Saudi Arabia. Arab World English Journal, 11(3), 226-240. https://doi.org/10.24093/awej/vol11no3.14

Brinkmann, S., \& Kvale, S. (2018). Doing interviews (2nd ed.). City Road: Sage. https://doi.org/10.4135/9781529716665

Chaiklin, S., \& Lave, J. (1993). Understanding practice: Perspectives on activity and context. Cambridge: Cambridge University Press. https://doi.org/10.1017/CBO9780511625510

Chinnery, G. M. (2008). You've got some GALL: Google-assisted language learning. Language Learning \& Technology, 12(1), 3-11.

Cohen, L., Manion, L., \& Morrison, K. (2018). Research methods in education (8th ed.). London: Routledge. https://doi.org/10.4324/9781315456539

Davies, J. (2012). Facework on Facebook as a new literacy practice. Computers and Education, 59(1), 19-29. https://doi.org/10.1016/j.compedu.2011.11.007

Davies, J. (2013). Trainee hairdressers' uses of Facebook as a community of gendered literacy practice. Pedagogy, Culture and Society, 21(1), 147-169. https://doi.org/10.1080/14681366.2012.748678

Duff, P. A., \& Doherty, L. (2014). Examining agency in (second) language socialization research. In P. Deters, X. Gao, E. R. Miller \& G. Vitanova (Eds.), Theorizing and analyzing agency in second language learning: Interdisciplinary approaches (pp. 54-72). Bristol: Multilingual Matters. https://doi.org/10.21832/9781783092901-006

Fattah, S. F. (2015). The effectiveness of using WhatsApp messenger as one of mobile learning techniques to develop students' writing skills. Journal of Education and Practice, 6(32), 115-127.

Finardi, K. R., Leao, R. G., \& Amori, G. B. (2016). Mobile assisted language learning: affordances and limitations of Duolingo. Education and Linguistics Research, 2(2), 48-65. https://doi.org/10.5296/elr.v2i2.9842

Friese, S. (2014). Qualitative data analysis with ATLAS.ti. (2nd ed.). London: Sage.

Gleason, B. (2016). New literacies practices of teenage Twitter users. Learning, Media and Technology, 41(1), 31-53. https://doi.org/10.1080/17439884.2015.1064955

Gleason, B. (2018). Thinking in hashtags: Exploring teenagers' new literacies practices on Twitter. Learning, Media and Technology, 43(2), 165-180. https://doi.org/10.1080/17439884.2018.1462207

Hamad, M. M. (2017). Using WhatsApp to enhance students' learning of English language "experience to share". Higher Education Studies, 7(4), 74-87. https://doi.org/10.5539/hes.v7n4p74

Hamilton, M. (2006). Just do it: Literacies, everyday learning and the irrelevance of pedagogy. Studies in the 
Education of Adults, 38(2), 125-140. https://doi.org/10.1080/02660830.2006.11661529

Infographics. (2016). A dictionary of social research methods (1st ed.). Oxford: Oxford University Press.

Ivanič, R., Edwards, R., Barton, D., Martin-Jones, M., Fowler, Z., Hughes, B. et al. (2009). Improving learning in college: Rethinking literacies across the curriculum. London: Routledge. https://doi.org/10.4324/9780203881422

Jones, R. (2017). Digital literacies. In E. Hinkel (Ed.), Handbook of research in second language teaching and learning (Vol. 3, pp. 286-298). New York: Routledge. https://doi.org/10.4324/9781315716893-21

Jones, R., \& Hafner, C. (2012). Understanding digital literacies: a practical introduction. London: Routledge. https://doi.org/10.4324/9780203095317

Kvale, S. (2007). Doing interviews. London: Sage. https://doi.org/10.4135/9781849208963

Lier, L. V. (2010). The ecology of language learning: practice to theory, theory to practice. Procedia Social and Behavioral Sciences, 3(2010), 2-6. https://doi.org/10.1016/j.sbspro.2010.07.005

Merchant, G. (2015). Apps, adults and young children: researching digital literacy practices in context. In R. H. Jones, A. Chik \& C. Hafner (Eds.). Discourse and digital practices: Doing discourse analysis in the digital age (pp. 144-157). New York: Routledge.

Minalla, A. A. (2018). The effect of WhatsApp chat group in enhancing EFL learners' verbal interaction outside classroom contexts. English Language Teaching, 11(3), 1-7. https://doi.org/10.5539/elt.v11n3p1

Morgan, D. L. (2008). Snowball sampling. In L. M. Given (Ed.), The SAGE encyclopedia of qualitative research methods (p. 816). Thousand Oaks: Sage.

Morgan, D. L., \& Hoffman, K. (2018). Focus groups. In U. Flick (Ed.), The SAGE handbook of qualitative data collection (pp. 250-263). London: Sage. https://doi.org/10.4135/9781526416070.n16

Saldaña, J. (2016). The coding manual for qualitative researchers (3rd ed.). Thousand Oaks: Sage.

Secker, J. (2017). The trouble with terminology: rehabilitating and rethinking 'digital literacy'. In K. Reedy \& J. Parker (Eds.), Digital literacy unpacked (pp. 3-16). London: Facet Publishing. https://doi.org/10.29085/9781783301997.003

Siri. (2020, October 11). Wikipedia, the free encyclopedia. Retrieved October 12, 2020 from https://en.wikipedia.org/wiki/Siri

Teske, K. (2017). Duolingo. CALICO Journal, 34(3), 393-401. https://doi.org/10.1558/cj.32509

Tiidenberg, K. (2018). Ethics in digital research. In U. Flick (Ed.), The SAGE handbook of qualitative data collection (pp. 466-479). London: Sage. https://doi.org/10.4135/9781526416070.n30

Tusting, K., Ivanič, R., \& Wilson, A. (2000). New literacy studies at the interchange. In D. Barton, M. Hamilton $\&$ R. Ivanič (Eds.), Situated literacies: Reading and writing in context (pp. 210-218). London: Routledge.

Warni, S., Abdul Aziz, T., \& Febriawan, D. (2018). The use of technology in English as a foreign language learning outside the classroom: an insight into learner autonomy. LLT Journal: A Journal on Language and Language Teaching, 21(2), 148-156. https://doi.org/10.24071/1tt.2018.210203

World Health Organisation. (2020, September 9). Timeline of WHO's response to COVID-19. Retrieved October 12, 2020 from https://www.who.int/news-room/detail/29-06-2020-covidtimeline

\section{Copyrights}

Copyright for this article is retained by the author, with first publication rights granted to the journal.

This is an open-access article distributed under the terms and conditions of the Creative Commons Attribution license (http://creativecommons.org/licenses/by/4.0/). 